CURRENT RESEARCH JOURNAL OF PHILOLOGICAL SCIENCES 2(10): 49-

53, October 2021

DOI: https://doi.org/10.37547/philological-crjps-02-10-10

ISSN 2767-3758

(C)2021 Master Journals

Crossref do

gil Google

Accepted26 ${ }^{\text {th }}$ October, 2021 \& Published $31^{\text {th }}$ October, 2021

\title{
COVERAGE OF FERGANA ARCHITECTURAL MONUMENTS IN ISHAKHON TORA IBRAT'S WORK “HISTORY OF FERGANA"
}

\author{
Eshonova N. Salimakhon
}

Candidate Of Philological Sciences, Associate Professor, Head Of Department Of Oriental Classical Literature Of The Institute Of Oriental Studies Named After Abu Rayhan Beruni Of The Academy Of Sciences Of The Republic Of Uzbekistan

\section{ABSTRACT}

It is known that Ishakhon Tora Ibrat's (1874-1922) "History of Fergana" is a valuable source of information on the social, cultural and diplomatic history of the entire valley and even neighboring Kyrgyzstan, Kashgar, Tajikistan, Turkestan, parts of Kazakhstan are political,, which belonged to the territory of the Kokand Khanate at that time. It also contains information on the history of architectural monuments in these areas. They can be classified into three groups: 1) The play compiles the history of who built the monument, when and where; 2) The history of the monument is filled with new information; 3) Religious legends about the monument are given.

The article illustrates these groups on the basis of examples and shows the importance of Ishakhon Tora Ibrat's work "History of Fergana" in filling in the information on the history of architectural monuments of Fergana.

KEYWORDS: - Amir al-Muslim, History of Fergana, medicine, astronomy, literature, art, architectural monuments, Umarkhan mosque, Kyrgyzstan, Kashgar, Tajikistan, Turkestan, and Kazakhstan, Amir alMuslim.

\section{INTRODUCTION}

History is such a comprehensive concept that it applies to every aspect of our lives. Whether it is medicine, astronomy, literature, art, each has its own history.

Although Ishakhon Tora Ibrat's (1874-1922) "History of Fergana" is so called, it contains not only the present-day Fergana, but also the entire valley of the Kokand Khanate at that time, and even parts of neighboring Kyrgyzstan, Kashgar, Tajikistan, Turkestan, and Kazakhstan, is a valuable source of information on social, cultural, diplomatic history.

\section{THE MAIN FINDINGS AND RESULTS}

Typically, the historian uses a unique part of his work in a compilation of the works of his predecessors, and covers the history of his time, for the most part, as a witness. This also applies to the history of architectural monuments.

Ishakhon Tora Ibrat's "History of Fergana" provides information on the history of architectural monuments in the following order:

1. Direct monument history: information about who built it, when, where, is compiled.

2. The existing history is filled with new information. 
CURRENT RESEARCH JOURNAL OF PHILOLOGICAL SCIENCES 2(10): 49-

53, October 2021

DOI: https://doi.org/10.37547/philological-crjps-02-10-10

ISSN 2767-3758

(C)2021 Master Journals

\section{crossref do) 801 Google}

Accepted26 ${ }^{\text {th }}$ October, 2021 \& Published $31^{\text {th }}$ October, 2021

3. Religious legends about the monument are given.

1. The direct history of the monument in the play: a compilation of information about who built it, when, where. The fact that the father-inlaw and minister of the Kokand khan Khudoyorkhan, Muslimkul, built a madrasah named after Khudoyorkhan in place of the old Horde of the previous khans, is written in prose and poetry in many sources [4: 212; 9: 118; $10: 30 ; 12: 185]$. The same information is given in the "History of Fergana": In Khokand he built a madrasah named after Khudoyorkhan. It was the arch of the Hoqand horde where the land had previously passed. It was built in $1272 \mathrm{AH}$ " [8]

2. Filling the existing history of the game with new information. At the same time, as the historian speaks about our past in his work, there are places where his predecessors expressed their creativity by supplementing it with the information he collected. Although the play does not describe the full history of the architectural monument, on the contrary, we see information that complements it, directing us to find a source related to it. For example, the history of the mosque in Kokand is mentioned in more than 20 historical and literary sources of its time and later. They include the date of construction of the monument from 1812 to 1818, information about its function as a mosque, madrasa, both a mosque and a madrasa, the rulers who built and repaired it, that is, Olimkhan from Kokand khans began its construction as a madrasa, Umarkhan mosque and madrasa Khudoyorkhan repaired and built a minaret in his yard, and Umarkhan started the construction of the monument when he received the title of Amir al-Muslim after the conquest of Turkestan.

However, none of them describes the reality before the construction of the monument and the reason for the nickname "Paradise". This event is described in the book "History of Fergana" as follows: "In the Umarkhan era, building a madrasah, developing knowledge, and introducing the rules of Sharia were in the picture. When he said, "The one who lays the foundation stone is the one who lays the stone, which has not been recommended since puberty", the khan himself said: "Alhamdulillah, I have never left it in my life!" When he laid the foundation stone, the ulama gave him the nickname "Paradise" for a century" [8]

At this point, we found it necessary to pay attention to another issue. Sources on the history of Kokand state that Amir Umarkhan was given the title of Amir al-Muslim, according to which "... the scholars issued a fatwa stating that whichever king paid twelve thousand people should be called Amir al-Muslim. At that time, the number of those who received salaries and pensions from the state of Amir Umarkhan reached forty thousand" [11: 345].

In fact, when literary and historical sources describe Amir Umarkhan, along with the title of Amir al-Muslim, the nickname "paradise" is often mentioned, but the reason for it is not explained. In the example of the above quote in Ibrat's work "History of Fergana" it can be seen that this issue is also clarified.

Therefore, this quote is a small episode, at first glance, it seems to be brief information, but in fact it serves to fill the history of the mosque madrasah, to shed more light on the personality of Amir Umarkhan, to express our values, the high status of the khan's etiquette.

3. The role of religious narrations in the work in filling the history of monuments. It is known that there are many religious legends about the history of monuments. Some have fallen into the form of local, verbal information, the sources of which, of course, are not mentioned. Muhammad 
CURRENT RESEARCH JOURNAL OF PHILOLOGICAL SCIENCES 2(10): 49-

53, October 2021

DOI: https://doi.org/10.37547/philological-crjps-02-10-10

ISSN 2767-3758

(C)2021 Master Journals

Crossref do

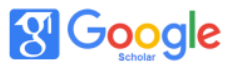

Accepted $26^{\text {th }}$ October, 2021 \& Published $31^{\text {th }}$ October, 2021

ibn Jarir, a commander who came to the Fergana Valley to spread Islam, was mentioned in Weiss Hirmani and Sadullah Hirmani's Manoqibi Khoja Kabul Akhbar Wali, Jamal Qarshi's "Mulhaqot bis-surah", and Hakim Khalis's "Shah Jarir's War". Ishaqkhan Tora Ibrat's "History of Fergana" combines the narrations of the activities of Muhammad ibn Jarir in the sources "Ka'b ulakhbar manoqibi", "Mulhaqat bi-s-suroh", "Tarihi shahi Jarir" and mentions the source of information about him. For example, in the "King of History Jarir" he wrote: "... In the time of 'Uthman, Muhammad Jarir bin Abdullah came and he also conquered many lands. As a caravan leader, he made a false pledge of allegiance, and in the end he killed the Arabs with a large army, and the rest went to Arabia.

"... the events of Jarir bin Abdullah in the time of Hadrat 'Uthman were that most of the cities of Turkestan were Islamabad, ... the capital was always far away ... and the Muslims were in disarray. At that time, two people from this city went to Arabia to complain: He said, "We will save the people of Islam from the pagans." At that time, Jarir bin Abdullah, the grandson of 'Uthman, was sent as an emir from' Uthman's side. ... (Jarir bin Abdullah) The king of Ahshid in Kasan went to fight the snake. ... (Akhshid) The governor of Ongar fled to Karvonbas degon. ... (Jarir bin Abdulloh) ... He converted Kasan to Islam, then went to Ongar, and when he sent a letter to the caravan, believing it falsely, ... he gave a beautiful daughter ... as a gift, and after some time prepared secret weapons, He killed the Arabs while they were standing, martyred many of the Companions and the Tabi'een, and fled. ... There are historical deaths and tombs inscribed on the graves of martyrs" [8].

Although this information has become a legend, it serves as a source for the history of the Bibi Ubayda and Safed Boulogne monuments that have survived to our day. For example, according to the legends about the history of Bibi Ubayda mausoleum in Buvayda district of Fergana region, Bibi Ubayda is the daughter of one of the rulers of Fergana - Karvonbas. The caravan converted to Islam from a lie, married his daughter, Bibi Ubayda [17], to the commander, Muhammad Jarir [18], and then assassinated him in order to keep his word. Bibi Ubayda, who converted to Islam, passed on her father's plot to her husband, Muhammad Jarir. However, the commander was attacked by the enemy while praying with his army. He survives with a few soldiers after a fierce battle. The surviving soldiers return to Medina with their wives. Bibi Ubayda has a son there. He is called Muhammad Fazil. When his son grew up, like his father, he was sent to his native Fergana to strengthen Islam. But just like his father, he is attacked and dies. He was popularly known as King Fazil. According to local sources, Bibi Ubayda died under the sand in a stormy wind in the Fergana desert while on her way to Madinah with her daughter-in-law and young granddaughter [3: 57-59; 15: 206]. Later, a mausoleum was built over his tomb. In the scientific literature, the mausoleum of Bibi Ubayda is interpreted as a monument of the Timurid period [13: 229]. Archaeological excavations in 1988 showed that the mausoleum was built on a building dating back to the Karakhanid period. Therefore, the tombstone preserved in the shrine today belongs to the same period [15: 206].

Shah Fozil's mausoleum is located in the village of Safed Bulon in the Olabuka district of the JalalAbad region of Kyrgyzstan, which borders the Kasan district of the Namangan region of Uzbekistan. It is a monumental complex, which includes the tombs of King Fozil, Safed Boulogne, several tombs, as well as sharp tombstones, which are considered to be outstanding examples of calligraphy of their time and are decorated with unique patterns $[16 ; 6]$. 
CURRENT RESEARCH JOURNAL OF PHILOLOGICAL SCIENCES 2(10): 49-

53, October 2021

DOI: https://doi.org/10.37547/philological-crjps-02-10-10

ISSN 2767-3758

(C2021 Master Journals

Crossref do

\section{Google}

Accepted26 th October, 2021 \& Published 31 ${ }^{\text {th }}$ October, 2021

Such graves are stored in the State Museum of the History of Culture of Namangan region. They are very similar to the tombs of Ispid / Safid Boulogne (Shah Fazil Complex) in terms of shape, silence in their inscriptions, pattern decoration and period [5: 61-72; 7; 14: 344-345].

\section{Conclusion}

In conclusion, Ishakhon Tora Ibrat's work "History of Fergana" has a special significance as an auxiliary historical material in filling the information on the history of architectural monuments.

\section{REFERENCES}

1. Abdulahatov N., Ostanaqulov I. (2014) Pilgrimages and shrines of Uzbekistan. Tashkent. (Абдулахатов Н., Останақулов И. Ўзбекистон зиёратгохлари ва қадамжолари. Тошкент, 2014.)

2. Abdulahatov N., Rahmonov A. Ahmedov M. (2013) Shrines in Buvayda. - Tashkent. (Абдулахатов Н., Рахмонов А. Ахмедов М. Бувайда зиёратгохлари. Тошкент, 2013.)

3. Abdulahatov N., Haydarova Z., Azimov 0. (2009) Shrine of Bibi Ubayda. - Fergana. (Абдулахатов Н., Хайдарова 3., Азимов 0. Биби Убайда зиёратгохи. Фарғона, 2009.)

4. Avazmuhammad Attor Khoqandi. Historical worldview. Translator from Persian-Tajik language, author of introductions and comments Sh.Vakhidov. (2012) - Tashkent. (Авазмухаммад Аттор Хўқандий. Тарихи жахоннамойи / Форс-тожик тилидан таржимон, кириш ва изохлар муаллифи Ш.Вохидов. Тошкент, 2012.)

5. Goryacheva V.D., Nastich V.N. (1984) Epigraphic monuments of Safid-Bulan XII XIV. Epigraphy of the East. No. XXII. - pp. 61-72. (Горячева В.Д., Настич В.Н.
Эпиграфические памятники Сафидбулана XII - XIV. / Эпиграфика Востока. №XXII 1984. Cc. 61-72.)

6. Religion, history and tourism ": Safed Boulogne, a new discovery by Kyrgyzstanis // http://uz.kloop.asia/2017/08/24/dintarih-va-turizm-ir-izistonliklar-yangi-kashfila-boshlagan-safed-bulon

7. Zasypkin B.N. Monuments to Kasan and Safit Bulenda. Committee for the Protection of Monuments of Material Culture under the Council of Ministers of the SSR. Inv. No. 72 (5) - pp. 3-36. (Засыпкин Б.Н. Памятники Касана и Сафит Буленда / Комитет по охране памятников материальной культуры при Совете Министров ССР. Инв. № 72(5)/3-36.)

8. Iskhokhon Tora Ibrat. "History of Fergana”// http://e-tarix.uz/milliyatinsholari/166-tarixi-fargona.html.

9. Mirzo Olim Mahdum Haji. History of Turkestan. Foreword and comments Sh. Vohidovniki, translated from Arabic script by Sh. Vohidov and R. Kholikova, indicators Sh.Vakhidov D. Sangirovaniki. 2008. Tashkent: New Century Generation. (Мирзо Олим Махдум хожи. Тарихи Туркистон / Сўзбоши ва изохлар Ш. Вохидовники, араб ёзувидан табдил Ш. Вохидов ва Р. Холиқованики, кўрсатгичлар Ш.Вохидов Д. Сангированики. Тошкент: Янги аср авлоди, 2008.)

10. Muhammadumar Umidi. Historian Turani. Translation, translator, author of introductions and comments Sh.Vakhidov. 2013. - Tashkent. (Мухаммадумар Умидий. Тарихчайи Туроний. / Табдил, таржимон, кириш ва изохлар муаллифи Ш.Вохидов. Тошкент, 2013.)

11. Muhammadhakimkhan Tora. Muntaxab at- 
CURRENT RESEARCH JOURNAL OF PHILOLOGICAL SCIENCES 2(10): 49-

53, October 2021

DOI: https://doi.org/10.37547/philological-crjps-02-10-10

ISSN 2767-3758

(C)2021 Master Journals

Crossref doi) 81 Google

Accepted $26^{\text {th }}$ October, 2021 \& Published $31^{\text {th }}$ October, 2021

tavorix. (History of Khokand and Bukhara, travel and memories). Translator from Persian-Tajik language, introduction, author of comments Sh.Vakhidov. Tashkent. 2010. (Мухаммадхакимхон тўра. Мунтахаб ат-таворих. (Хўқанд ва Бухоро тарихи, саёхат ва хотиралар) / Форс-тожик тилидан таржимон, муқаддима, изохлар муалифи Ш.Вохидов. Тошкент, 2010.)

12. Niyaz Muhammad Hoqandi. Ibratu-lhavoqin (History of Shahrukh). Translator, translator, introduction and author of comments Sh.Vakhidov. (2014) - Tashkent: Turon-ziyo. (Ниёз Мухаммад Хўқандий. Ибрату-л-хавоқин (Тарихи Шохрухий). / Таржимон, табдил, кириш ва изохлар муаллифи Ш.Вохидов. Тошкент: Туронзиё, 2014.)

13. National Encyclopedia of Uzbekistan. Tashkent. 2001. Vol 2. (Ўзбекистон миллий энциклопедияси. Тошкент, 2001. T.2.)

14. Inscriptions on the monuments of Uzbekistan. Namangan. Authors of readings, translations and comments, introductory and concluding texts: S.Fayzieva, A.Turdialiev. - Tashkent: Uzbekistan Today, 2015. (Ўзбекистон обидаларидаги битиклар. Наманган / Битикларнинг ўқилиши, таржима ва изохлар, кириш ва хулоса матнлари муаллилари: С.Файзиева, А.Турдиалиев. Тошкент: O`zbekistan Tuday, 2015.)

15. Inscriptions on the monuments of Uzbekistan. Fergana. Authors of readings, translations and comments, introductory and concluding texts: S.Fayzieva, A.Turdialiev. Tashkent: Uzbekistan Today, 2016. (Ўзбекистон обидаларидаги битиклар. Фарғона / Битикларнинг ўқилиши, таржима ва изохлар, кириш ва хулоса матнлари муаллифлари: С.Файзиева, А.Турдиалиев. Тошкент: O`zbekistan Tuday, 2016.)

16. http://www.foto.kg/galereya/325gumbez-shah-fazil-xvi-v.html;

17. According to some sources, Bibi Ubayda is sometimes interpreted as the mother of Shah Jarir, the commander, and sometimes as his wife. See: [15:13; 3: 57-71, 83-86, 9091, 95-101; 1: 64-67].

18. Muhammad Jarir - The Prophet Muhammad (s.a.v.) married his daughter Gulsum to Uthman (r.a.). After Gulsum's death, he also married his eldest daughter, Zaynab, to him, so 'Uthman (r.a.) took the nickname zu-nnurayn - the owner of two lights. The son of Uthman and Zaynab was named Muhammad Jarir, who became famous among the people as King Jarir. In some narrations, Muhammad is interpreted as Jarir ibn Abdullah ibn Uthman, that is, the grandson of Uthman (ra). See [2:19; 8]. 